\title{
REPRODUCTIVE BIOLOGY OF THE SOUTHERN PUFFERFISH, SPHOEROIDES NEPHELUS (ACTINOPTERYGII: TETRAODONTIFORMES: TETRAODONTIDAE), IN THE NORTHERN COAST OFF THE YUCATAN PENINSULA, MEXICO
}

\author{
Jorge Carlos PENICHE-PÉREZ1 ${ }^{1}$ Carlos GONZÁLEZ-SALAS ${ }^{2}$, \\ Harold VILLEGAS-HERNÁNDEZ², Raúl DÍAZ-GAMBOA², Alfonso AGUILAR-PERERA², \\ Sergio GUILLEN-HERNÁNDEZ², and Gaspar R. POOT-LÓPEZ ${ }^{2 *}$ \\ ${ }^{1}$ Unidad de Ciencias del Agua, Centro de Investigación Cientifica de Yucatán, Cancún, Quintana Roo, México \\ ${ }^{2}$ Departamento de Biología Marina, Facultad de Medicina Veterinaria y Zootecnia, Universidad Autónoma \\ de Yucatán, Mérida, Yucatán, México
}

Peniche-Pérez J.C., González-Salas C., Villegas-Hernández H., Díaz-Gamboa R., Aguilar-Perera A., GuillenHernández S., Poot-López G.R. 2019. Reproductive biology of the southern pufferfish, Sphoeroides nephelus (Actinopterygii: Tetraodontiformes: Tetraodontidae), in the northern coast off the Yucatan Peninsula, Mexico. Acta Ichthyol. Piscat. 49 (2): 133-146.

\begin{abstract}
Background. Overexploitation of fishery resources has led to the capture of alternative species of a lower trophic level, considered previously unprofitable or unfit for human consumption. The southern pufferfish, Sphoeroides nephelus (Goode et Bean, 1882), is a bycatch species of the recreational fishery in the USA and Mexico. Unlike other species of the genus Sphoeroides, there is no background on their reproductive cycle. Therefore, this study aimed to describe several reproductive traits (sex ratio, gonadal development, annual reproductive cycle, and fecundity) of specimens from the northern coast of the Yucatan Peninsula, Mexico. This kind of information might serve as a point of reference for its potential use either in the pharmaceutical industry, aquarium trade, as well as in aquaculture.

Materials and methods. The reproductive biology of the southern pufferfish was described based on 189 females and 223 males, caught off the northern coast off the Yucatan, Mexico, during an annual cycle. Several reproductive traits, such as the annual cycle of gonad development, sex ratio, and the batch fecundity were determined.

Results. The sex ratio showed no significant difference from $1 \div 1$ ratio. Male's reproductive season lasted from August to May, although females were spawning from August to April. The size at 50\% maturity was estimated at $14.93 \mathrm{~cm}$ TL for females. Batch fecundity ranged between 59087 and 367022 oocytes (mean 176456 ) per spawning batch, and it was significantly fitted to both female size and weight based on power and linear regression models, respectively. The relative batch fecundity was estimated at $828 \pm 182$ oocytes per gram of eviscerated weight, and $11989 \pm 4774$ oocytes per gram of gonad weight.

Conclusions. It was determined that $S$. nephelus exhibited $1 \div 1$ sex ratio, an asynchronous development of oocytes and indeterminate fecundity with batch spawning. The species has a protracted reproductive season that lasted almost all year round with peaks in February-March (before of the dry season) and a brief inactive period in June-July (before of the wet season). This latter information should be helpful to obtain a broodstock that would be the base to produce fingerlings to be raised, instead of collecting individuals from the wild.
\end{abstract}

Keywords: gonadal development, annual reproductive cycle, fecundity, southern pufferfish, Yucatan

\section{INTRODUCTION}

Overfishing has often resulted in a progressive shift in target species to those of lower trophic level or to species previously considered unprofitable and of low quality for human consumption (Sala et al. 2004, McConney 2011). While the economic and nutritional potential of alternative species is acknowledged, many of them are also important in the structure and functioning of marine ecosystems (Pauly and Palomares 2005). Therefore, before taking advantage of a species, important aspects of its biology, habitat, and ecology must be known. Sex ratio, size of sexual maturity, and time and duration of

* Correspondence: Dr. Gaspar R. Poot López, Departamento de Biología Marina, Facultad de Medicina Veterinaria y Zootecnia, Universidad Autónoma de Yucatán, Mérida, Yucatán, México, Phone: +52 9999423200, fax: +52 9999423205, e-mail/ORCID: (GRPL) gaspar.poot@correo.uady.mx, ORCID: 0000-0002-1905-7117, (JCPP) squalo132@hotmail.com, ORCID: 0000-0002-8285-2439, (CGS) carlos.gonzalez@correo.uady.mx, ORCID: 0000-0002-7578-3535, (HVH) harold.villegas@ correo.uady.mx, ORCID: 0000-0002-3197-6132,(RDG) raul.diaz@correo.uady.mx, ORCID: 0000-0002-6979-1758, (AAP) alfonso.aguilar@correo.uady.mx, ORCID: 0000-0002-7579-2183, (SGH) ghernand@correo.uady.mx, ORCID: 0000-0002-8419-6092. 
the reproductive period, represent critical components in fish population dynamics linked to the ecological niches, social patterns, and the different morpho-physiological specializations (Villacorta-Correa and Saint-Paul 1999, Murua and Saborido-Rey 2003, Brown-Peterson et al. 2011, Lowerre-Barbieri et al. 2011). Globally, the pufferfish family (Tetraodontidae) includes 29 genera and 200 species (Froese and Pauly 2018), of which at least 11 species (two genera) are used for human consumption (Dore 1991, Oliveira et al. 2003). However, many pufferfishes bioaccumulate tetrodotoxin (TTX), especially in viscera and gonads. The TTX is acquired through the trophic web (Burklew and Morton 1971, Noguchi et al. 2006, Abbott et al. 2009, Arakawa et al. 2010). In some Mediterranean countries, there is a market for invasive pufferfish, such as Lagocephalus sceleratus (Gmelin, 1789), especially by the aquarium industry and by the pharmaceutical industry to use of TTX as a molecular precursor of other substances (Kosker et al. 2016). In India, the use of pufferfish liver oil as a source of barbitone is being investigated (Mitra et al. 1989, Ghosh et al. 2005). In addition, since it has been observed that their toxicity is considerably reduced when pufferfish are grown in controlled systems, some of these species are known as suitable for human consumption and thus receive good acceptance in Asian markets (Noguchi et al. 2006, Chávez Sánchez et al. 2008, Arakawa et al. 2010). Particularly, the genus Sphoeroides represents an important source of protein in different parts of the world. During World War II, this fish supported commercial fisheries on the east coast of the United States (Laroche and Davis 1973, Deeds et al. 2008). Currently, in Japan, some species of Sphoeroides are consumed regularly due to its white flesh, few bones, and the ease of capture and processing (Abbott et al. 2009, Abdo de la Parra et al. 2013). The southern pufferfish, Sphoeroides nephelus (Goode et Bean, 1882), is a common bycatch species of recreational fishing in Yucatan, Mexico (Poot-López et al. 2017), Florida in the United States (Abbott et al. 2009), and in artisanal shrimp fishing (Poot-Salazar et al. 2009). It is commonly found in the western Atlantic throughout most of the Caribbean Sea in the eastern part of the Gulf of Mexico; rarely along the Central American coast and is absent from the South American coast (Collette 2002). It frequents shallow water of bays and estuaries to depths of $20 \mathrm{~m}$. Studies on S. nephelus in different parts of the world have focused mainly on feeding habits (Carr and Adams 1973, Mallard-Colmenero et al. 1982, PalaciosSánchez and Vega-Cendejas 2010), ecology (Weinstein and Heck 1979, Vega-Cendejas 2004), toxicology (Burklew and Morton 1971, Landsberg et al. 2006, Abbott et al. 2009), and the length-weight relation (MallardColmenero et al. 1982, Poot-López et al. 2017). However, a controversy exists about the toxicity of $S$. nephelus for human consumption, as there are regional and individual variations. Consequently, some studies mention that their meat is safe to consume, whereas others note that it is highly toxic (Burklew and Morton 1971, Deeds et al. 2008, Abbott et al. 2009).
Unlike other species of the genus Sphoeroides, little is known on the reproductive cycle of $S$. nephelus, except a preliminary study from Campeche, Mexico (MallardColmenero et al. 1982). Due to the lack of information related to the reproductive biology of the southern pufferfish, Sphoeroides nephelus, throughout its range of distribution, this study aimed to describe several reproductive traits (sex ratio, gonadal development, annual reproductive cycle, and fecundity) of specimens from the northern coast of the Yucatan Peninsula, Mexico.

\section{MATERIALS AND METHODS}

Study Area. Chuburná Puerto $\left(22^{\circ} 13^{\prime} 57.2^{\prime \prime} \mathrm{N}\right.$, $89^{\circ} 53^{\prime} 25.0^{\prime \prime} \mathrm{W}$, Fig. 1) is located in the northern Yucatan Peninsula where a warm semi-dry climate predominates from March to June, with intense rains from July to October, and strong north winds and lower intensity rains the rest of the year (Herrera-Silveira, 1994). The mean annual temperature is $25.6^{\circ} \mathrm{C}$, with the highest temperatures usually recorded in May $\left(27^{\circ} \mathrm{C}\right)$ and the lowest recorded in January $\left(20^{\circ} \mathrm{C}\right)$. The winter season is characterized by the entrance of northern cold fronts (known locally as 'nortes'), which bring rainfall and lower temperatures (Ordoñez-López et al. 2013).

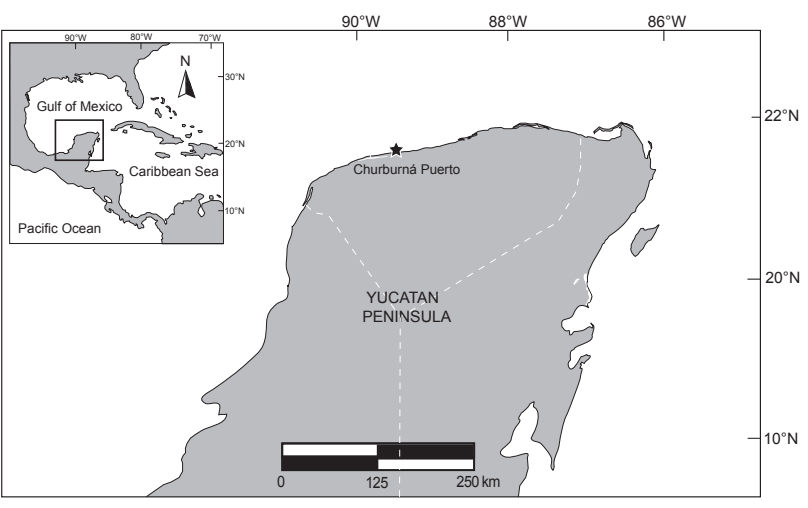

Fig. 1. Location of the study area and the sampling site along the coast off Chuburná Puerto in the northern coast of the Yucatan Peninsula, Mexico

Monthly samples of Sphoeroides nephelus were taken with hook and line on the coastal area off Chuburná Puerto known as part of a recreational fishing study developed from October 2015 to September 2016, within a coastal area characterized by rocky reefs, with depths between 4 and $5 \mathrm{~m}$.

In the laboratory, specimens were measured to the nearest $0.1 \mathrm{~cm}$ to obtain the total length (TL). Once total body weight (TW) was taken on each specimen to the nearest $0.01 \mathrm{~g}$, all samples were dissected and eviscerated, and the eviscerated body weight $\left(W_{\mathrm{E}}\right)$, liver weight $\left(W_{\mathrm{L}}\right)$, and the gonad weight $\left(W_{\mathrm{G}}\right)$ were obtained to the nearest $1 \mathrm{mg}$. The gonads were then fixed in Bouin's solution for further histological processing and fecundity estimations. Histological analysis of the gonads. A histological study of the gonads of each individual was carried out to determine the stages of development of their gametes. 
Central portions (transverse sections) of the fixed gonads were dehydrated and embedded in paraffin, sectioned at between 5-7 $\mu \mathrm{m}$, depending on their state of gonadal development (early phases required thinner sections in order to facilitate the identification of their gametes, and then stained with haematoxylin-eosin (Awruch et al. 2008, Villegas-Hernández et al. 2016). Gonadal phases of development for females and males were classified following Brown-Peterson et al. (2011) as immature, developing, spawning capable, regressing, and regenerating. It should be noticed that in order to identify the gonadal phases, histological observation was applied to detect oocytes with a more advanced stages, whether primary growth (PG), cortical alveoli (CA), vitellogenic (Vtg1, Vtg2, Vtg3), germinal vesicle migration (GVM), or hydrated $(\mathrm{H})$, independently of their frequency (BrownPeterson et al. 2011, Lowerre-Barbieri et al. 2011). Moreover, the ovarian wall thickness was considered a key factor in distinguishing between immature and regenerating phases, since a thin ovarian wall is commonly observed in immature specimens whereas a thick ovarian wall (along with atretic oocytes) was observed in specimens at the regenerating phase (Brown-Peterson et al. 2011, VillegasHernández et al. 2016). Prior to this, it was verified that the development of the oocytes was uniform throughout the gonad, performing three dissections of each lobe (anterior, middle and posterior sections) in ovaries of the same fish. This procedure was repeated for 10 females. Since the same reproductive phase was assigned for all 10 samples, only one sample from the mid-portion of each gonad was analysed.

In the case of males, the immature phase was characterized by spermatogonia in the germinal epithelium and by the absence of lumen within the lobules. The developing phase was histologically identified by the presence of a continuous germinal epithelium with spermatocysts undergoing active spermatogenesis and the formation of a lumen in the lobule. The spawning capable phase was identified by the presence of spermatozoa in the lumen of the lobules and in the sperm ducts. Males in the regressing phase were histologically identified by depleted stores of spermatozoa in the sperm ducts and in the lumen of lobules. Finally, the regenerating phase for males was characterized by spermatogonial proliferation in the lobules throughout the testes, but in contrast to immature males, some residual spermatozoa remained distinguishable in the sperm duct and in the lumen of the lobules of males in the regenerating phase.

Spawning season and fish condition. Gonadosomatic index (GSI), as a proxy of the degree of gonadal development, was calculated for each individual based on eviscerated weight to avoid possible variations from differences in stomach contents using the formula

$$
\mathrm{GSI}=100 W_{\mathrm{G}} \cdot W_{\mathrm{E}}^{-1}
$$

where $W_{\mathrm{G}}$ is the gonad weight, and $W_{\mathrm{E}}$ is the eviscerated weight of fish. Occurrence of spawning of $S$. nephelus was inferred from the presence of postovulatory follicles (females) and large and firm testes with spermatozoa in the lumen of lobules and sperm ducts (males) along with both the GSI variation and the increased frequency of spawning-capable specimens according the maturity phases (expressed in relative frequency) found throughout the year (deVlaming et al. 1982, Lowerre-Barbieri et al. 2011). In addition, since the hepatosomatic index (HSI) may provide information about the processes of storage and transfer of proteins and lipids associated with the reproductive effort in puffer species (Santos et al. 1996, Piah and Bucher 2014), it was also estimated for each individual as

$$
\mathrm{HSI}=100 W_{\mathrm{L}} \cdot W_{\mathrm{E}}^{-1}
$$

where $W_{\mathrm{L}}$ is the liver weight.

The length-weight relation (LWR) was estimated by the power regression model (Le Cren 1951) modified as follows

$$
W_{\mathrm{E}}=a \mathrm{TL}^{b}
$$

Additionally, the somatic condition was evaluated by the relative condition factor $\left(K_{\mathrm{n}}\right)$ (Le Cren 1951), using the formula of Copp (2003)

$$
K_{\mathrm{n}}=100 W_{\text {Eobs }} \cdot W_{\text {Eexp }}^{-1}
$$

where $W_{\text {Eobs }}$ is the observed eviscerated weight and $W_{\text {Eexp }}$ is the expected weight which was determined by using the LWR for all individuals in the study.

Fecundity estimates. Firstly, in order to determine the size range of the oocytes at different stages of development (PG, CA, Vtg1, Vtg2, and Vtg3), the diameters of 50 oocytes in each of these stages of development were measured. Then, the presence of advanced vitellogenic oocytes $(\mathrm{Vtg} 3)$ was determined to select suitable specimens for fecundity estimation and discarding those with ovaries that presented post-ovulatory follicles (POFs), since its presence indicates that spawning of mature oocytes has occurred (Hunter and Macewicz 1985). Fecundity was estimated as batch fecundity (defined as the number of oocytes spawned per batch) for each specimen using the gravimetric method combined with image analysis as explained by Murua et al. (2003). This estimation facilitates the measurement (diameter in $\mu \mathrm{m}$ ) and the count of the oocytes in a subsample of a given weight (predefined arbitrarily approximately at $0.05 \mathrm{~g}$ to reduce any size effect of the subsample between estimates) taken from the central region of the ovary (Kraus et al. 2005, Gonçalves et al. 2009, Witthames et al. 2009). Batch fecundity $\left(F_{\mathrm{B}}\right)$ was estimated according to Hunter et al. (1985) with the formula

$$
F_{\text {B }}=W_{\text {Gfix }} \cdot\left(N_{\text {Oss }} \cdot W_{\text {Gss }}{ }^{-1}\right)
$$

where $W_{\text {Gfix }}$ is the gonad weight after fixation, $N_{\text {Oss }}$ is the number of hydrated oocytes in a subsample of ovarian tissue and $W_{\text {Gss }}$ is the subsample weight. Once weighed 
subsamples were taken from the ovary, oocytes were separated from connective tissue using a washing process (Lowerre-Barbieri and Barbieri 1993) and sorted by size through several sieves (from 800 to $100 \mu \mathrm{m}$ ). This latter procedure facilitated the subsequent work of counting and measuring oocytes using a computer-aided image analysis system named IMAGEJ V. 1.51 which generates plots of size frequency distributions of the diameters of the oocytes. The final selection of the specimens for fecundity estimates was based on those females showing size frequency distributions with most advanced vitellogenic oocytes (Vtg3), which were clearly about to outgrow the standing stock of vitellogenic oocytes and/or showed a separate mode of mature oocytes developed previously to ovulation (Murua et al. 2003).

Data analyses. Sex ratio was explored annually, monthly, and by size class ( $1 \mathrm{~cm}$ TL intervals). In all three cases,

chi-square test $\left(\chi^{2}\right)$ was applied, with the Yates continuity correction as

$$
\chi_{\text {Yates }}^{2}=\left[\sum\left(\left|f_{\text {obs }}-f_{\text {exp }}\right|-0.5\right)^{2}\right] \cdot f_{\exp }^{-1}
$$

where $f_{\text {obs }}$ is the observed frequency and $f_{\text {exp }}$ is the expected frequency, to compare male $\div$ female ratio equivalence to $1 \div 1$ (Zar 1999). However, to compare sex ratio per month and reduce the type I error in these comparisons, the level of significance was adjusted by the Bonferroni method $\left(\alpha \cdot k^{-1}\right.$ where $\alpha$ (significance $)=$ 0.05 and $k$ (comparisons) $=12$ months, that is to say, at $95 \%$ confidence and 12 monthly comparisons the required $p$-value to reject the null hypothesis $(1 \div 1)$ would be less than 0.0042 .

To determine, which fish condition factor whether Fulton's $K$ or Le Creen's $K_{\mathrm{n}}$ (Le Cren 1951) should be used, first it was necessary to determine what kind of growth either isometric or allometric $S$. nephelus presents. For that, a $t$-student test was used to comparing the slopes $(b=3$ vs. $b \neq 3$ ). To determine differences of the LWR between sexes, $a$ and $b$ parameters were obtained from linear regression of log-transformed data and an analysis of covariance (one-way ANCOVA) was applied, where $W_{\mathrm{E}}$ was the dependent variable, sex the factor and TL the co-variable. Then, $K_{\mathrm{n}}$ differences between sexes were evaluated with a Student's $t$-test for independent samples.

A Pearson correlation analysis was performed between HSI, GSI, and $K_{\mathrm{n}}$ to estimate the relation and association. In order to examine the mean seasonality (monthly) in fish condition, an analysis of variance on the HSI, GSI, and $K_{\mathrm{n}}$ were carried out at $95 \%$ confidence (separately per sex) and a posteriori Bonferroni's interval test, when significant differences were found. Normality was corroborated with the Shapiro-Wilks test and homoscedasticity with the Levene's test (Zar 1999). The relation between batch fecundity and size (TL), as well as batch fecundity and weight $\left(W_{\mathrm{E}}\right)$, was estimated by fitting power and linear functions, respectively. The relative batch fecundity was also calculated as batch fecundity per gram of weight $\left(W_{\mathrm{E}}\right)$ of the fish, as well as batch fecundity per gram of gonad weight $\left(W_{\mathrm{G}}\right)$ (Hunter et al. 1985, Murua et al. 2003).

Finally, size at $50 \%$ maturity $\left(L_{50}\right)$ was estimated to define sexual maturity as a function of body length (length at which $50 \%$ of the individuals were mature). Despite that we used Brown-Peterson's (2011) criteria for the identification of gonadal phases, the presence of stage III (vitellogenic oocytes along with the absence of POFs and atretic oocytes) was used instead as the criterion for female maturity, and then be able to generate a histology-based estimate of female size at maturity. Thus, to predict the probability that an individual was mature based on its length binary maturity observations ( $0=$ immature, $1=$ mature $)$ and length (TL) were fitted to binary logistic models to construct maturity ogives (maturity-at-length probability plots) based on logistic equations.

\section{RESULTS}

A total of 412 specimens of Sphoeroides nephelus were collected (Fig. 2), of which 189 were females, ranging from 12.9 to $29.8 \mathrm{~cm}$ (mean \pm standard deviation; 20.6 $\pm 3.1 \mathrm{~cm}) \mathrm{TL}$ and from 52.4 to $481.3 \mathrm{~g}(163.1 \pm 71.5 \mathrm{~g})$ eviscerated weight. Meanwhile, 223 were males ranging from 13.1 to $28.5 \mathrm{~cm}(20.3 \pm 2.9 \mathrm{~cm}) \mathrm{TL}$, and from 40.2 to $440 \mathrm{~g}(154.2 \pm 66.1 \mathrm{~g})$ eviscerated weight. After the Bonferroni's correction, sex ratio showed no significant difference from $1 \div 1(p$-value $=0.0042)$ neither by $1 \mathrm{~cm}$ TL size classes (Fig. 2), annually nor by month (Table 1). Despite that monthly samples did not differ from a $1 \div 1$ equivalence, it is noticeable that a higher proportion of males was observed from October to February, and then a higher proportion of females was observed from April to September (Table 1).

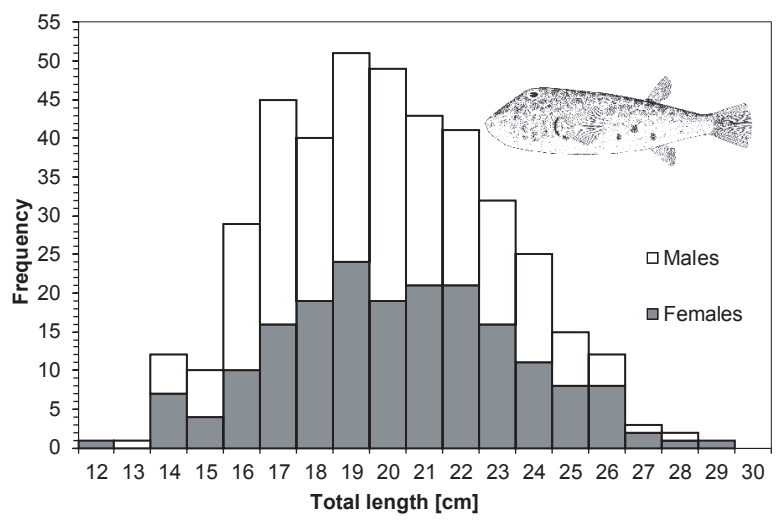

Fig. 2. Size-frequency distributions $(1 \mathrm{~cm}$ TL interval classes) for specimens of Sphoeroides nephelus sampled for this study per sex at the coast off Chuburná Puerto in the northern coast of the Yucatan Peninsula, Mexico

Length-weight relations (LWR) were fitted to power regressions models for females

$$
W_{\mathrm{E}}=0.0242 \cdot \mathrm{TL}^{2.8915}
$$

$\left(r^{2}=0.960, n=189\right)$, and males 


$$
W_{\mathrm{E}}=0.022 \cdot \mathrm{TL}^{2.9245}
$$

$\left(r^{2}=0.961, n=223\right)$. After LWRs were logarithmically transformed the analysis of comparison of regression lines between sexes showed no significant differences either in the intercepts $\left(F_{3,1}=0.18, p\right.$-value $\left.=0.6751\right)$ or the slopes $\left(F_{3,1}=0.40, p\right.$-value $\left.=0.5255\right)$. Since LWR did not differ between sexes, data were pooled and the LWR was estimated at

$$
W_{\mathrm{E}}=0.0231 \cdot \mathrm{TL}^{2.9073}
$$

$\left(r^{2}=0.9613, n=412\right)$. The slope $b=2.9073$ (standard error $=0.0288$ ) was found significantly different from 3 $\left(t_{0.05,410}=3.2181, p\right.$-value $\left.=0.0014\right)$, which in turn discards the use of Fulton's condition factor $(K)$ since it implies an isometric growth $(b=3)$, and the Le Creen's condition factor $\left(K_{\mathrm{n}}\right)$ was used instead.

Table 1

Monthly sex ratio of Sphoeroides nephelus off the coast of Chuburná Puerto, Yucatan

\begin{tabular}{lrrccc}
\hline \multicolumn{1}{c}{ Month } & Females & Males & $\begin{array}{c}\text { Sex ratio } \\
\text { Female } \div \text { Male }\end{array}$ & $\chi^{2}$ & $p$-value \\
\hline October & 12 & 23 & $1.0 \div 1.9$ & 2.86 & 0.0910 \\
November & 19 & 22 & $1.0 \div 1.6$ & 0.10 & 0.7548 \\
December & 7 & 23 & $1.0 \div 3.3$ & 7.50 & 0.0062 \\
January & 9 & 21 & $1.0 \div 2.3$ & 4.03 & 0.0446 \\
February & 10 & 20 & $1.0 \div 2.0$ & 2.70 & 0.1003 \\
March & 16 & 19 & $1.0 \div 1.2$ & 0.11 & 0.7353 \\
April & 22 & 15 & $1.5 \div 1.0$ & 1.35 & 0.2450 \\
May & 16 & 21 & $1.0 \div 1.3$ & 0.43 & 0.5108 \\
June & 20 & 13 & $1.5 \div 1.0$ & 1.52 & 0.2184 \\
July & 20 & 13 & $1.5 \div 1.0$ & 1.52 & 0.2184 \\
August & 19 & 18 & $1.1 \div 1.0$ & 0.05 & 0.8162 \\
September & 19 & 15 & $1.3 \div 1.0$ & 0.50 & 0.4795 \\
\hline Annual & 189 & 223 & $1.0 \div 1.2$ & 2.64 & 0.1040 \\
\hline
\end{tabular}

Gonadal development and spawning seasonality. In both sexes four gonadal phases were found: developing, spawning capable, regressing, and regenerating. Developing females showed oocytes in PG, CA, and in some cases Vtg1 (Fig. 3A, 3B). Besides CA, Vtg1, or Vtg2 oocytes, ovaries in spawning capable phase also showed Vtg3 (Fig. 3C, 3D) but few germinal vesicle migration (GVM) or hydrated oocytes (H). Meanwhile, those females with ovaries in regressing showed CA, Vtg1, Vtg2 oocytes plus some POFs and atretic oocytes (At) whose presence as well as the disorganized lamellae, spaced oocytes, and residual Vtg1-3 were all features of the regressing phase (Fig. 3E, 3F). Finally, females with ovaries in regenerating phase showed only PG and Vtg1 as well as a thick ovarian wall, along with atretic (At) oocytes (Fig. 3G, 3H), not so in the immature phase, whose ovarian wall is commonly thin in immature specimens. On the other hand, using the presence of stage III (vitellogenic oocytes) as the criterion for female maturity we could identify 16 females with this immature histological characteristic along with the absence of POFs and atretic oocytes. The size at 50\% maturity $\left(L_{50}\right)$ was estimated at $14.93 \mathrm{~cm}$ TL for females, and no immature individuals were found with TL greater than $18.0 \mathrm{~cm}$ (Fig. 4).

Only one male was immature with germinal epithelium and spermatogonia evidenced within the whole testis, meanwhile developing males presented mainly spermatogonia $(\mathrm{Sg})$, spermatocytes $(\mathrm{Sc})$, spermatids $(\mathrm{St})$, and in some cases scarce spermatozoa $(\mathrm{Sz})$ in the lumen of the gonad (Fig. 5A, 5B). Spawning capable males showed great accumulation and concentration of $\mathrm{Sz}$ in the lumen (Fig. 5C, 5D). Males in the regressing phase showed some residual $\mathrm{Sz}$ (Fig. 5E, 5F) and males in regenerating showed proliferation of Sc throughout testes as well as $\mathrm{Sg}$ and $\mathrm{Sc}$ in the periphery of the gonads (Fig. 5G, 5H).

Based on the monthly variation of the relative frequency of spawning capable phase, male's reproductive season occurred from August to May and non-reproductive season from June to July (Fig. 6). Similarly, females showed a reproductive season from August to April and non-reproductive season between May and July (Fig. 6). The monthly variation of GSI (mean \pm standard error) supported the annual spawning seasonality since a peak was evidenced on February (GSI $=2.2 \pm 0.3$ for males) and March (GSI = 5.39 \pm 1.15 for females), when higher relative frequencies of spawning capable specimens were also observed (Fig. 6). Regarding the reproductive cycle, similar trends in the gonadal development phases were found throughout the year in both sexes. Developing phases were observed mainly from June to January followed by spawning until May when subsequently the spawning ceased, and the regressing and regenerating phases became more evident in June and July (Fig. 6). In addition, the lowest GSI values corresponded to June and July, when a greater proportion of organisms was observed in the regressing and regenerating phases (Fig. 6).

Seasonality of the fish condition. Significant correlations (although weak) were observed only for the males between GSI and HSI $(R=0.26, p$-value $=0.0001)$ and between GSI and $K_{\mathrm{n}}(R=0.1686, p$-value $=0.0118)$. On the other hand, the correlation between the HSI and the $K_{\mathrm{n}}$ was significant, for both females $(R=0.15, p$-value $=0.0293)$ and for males $(R=0.19, p$-value $=0.0041)$.

ANOVAs on the condition indices to test their seasonality indicated that monthly mean GSI was significantly different, both in females $\left(F_{188,11}=5.24\right.$, $p$-value $<0.0001)$ and in males $\left(F_{222,11}=10.91, p\right.$-value $<0.0001)$. Multiple comparison tests indicated that there were significant differences between the monthly values of GSI, as shown in Fig. 6A, in which i.e., the values of February, March, and April were significantly higher compared to the rest either for males or females. On the other hand, the monthly variation of the HSI only turned out to be significant in males $\left(F_{222,11}=3.83, p\right.$-value $<$ $0.0001)$ but not in females $\left(F_{188,11}=1.83, p\right.$-value $=$ 0.0522) (Fig. 7B). After the months of intense reproductive activity (February to March) it was observed in both sexes that HSI decreased considerably, recovering in the months of reproductive inactivity (Fig. 7B). Likewise, the 

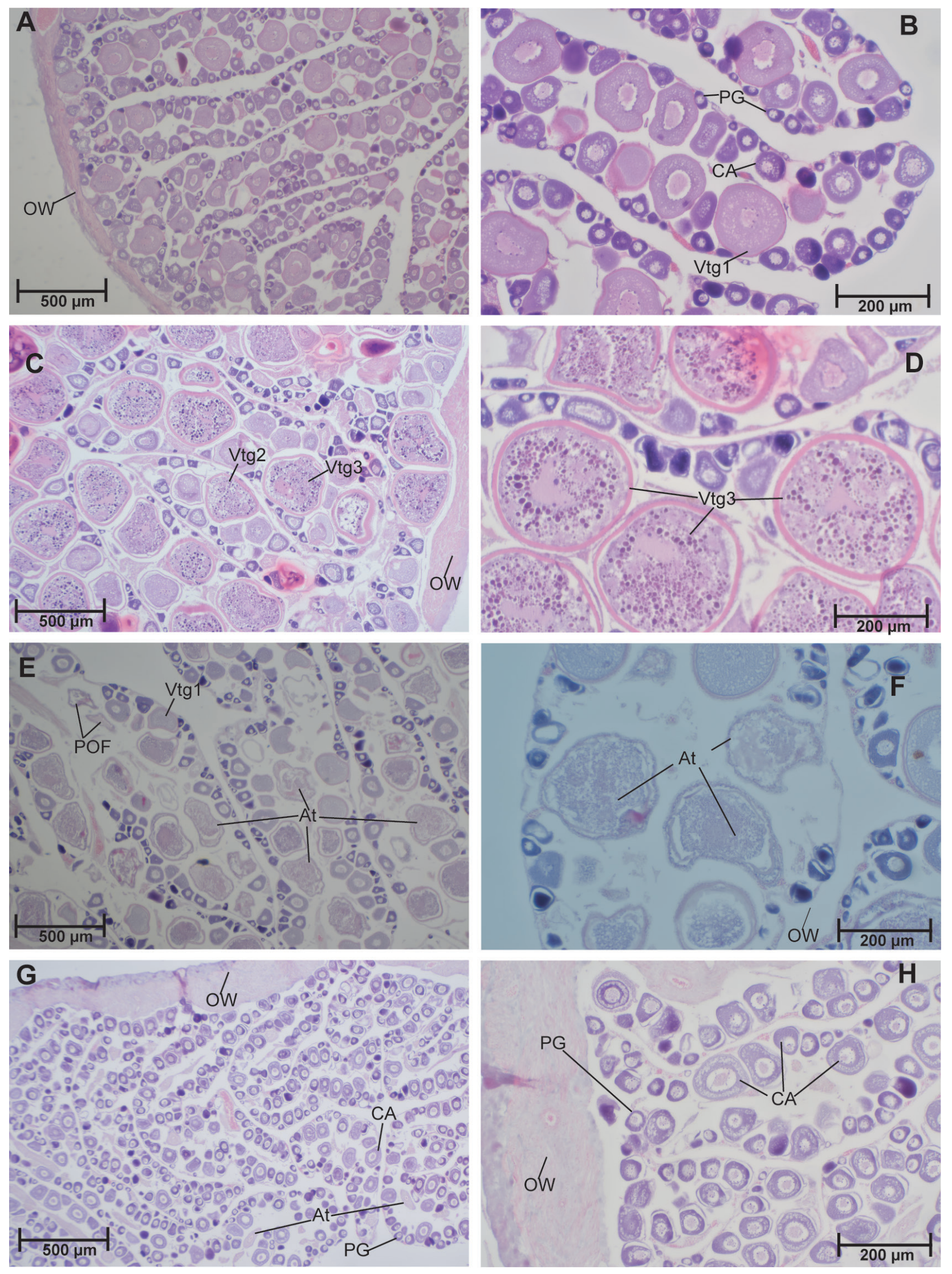

Fig. 3. Microphotographs of female gonads of Sphoeroides nephelus showing the reproductive phases considered in this study: developing $(\mathbf{A}, \mathbf{B})$, spawning capable $(\mathbf{C}, \mathbf{D})$, regressing $(\mathbf{E}, \mathbf{F})$, and regenerating $(\mathbf{G}, \mathbf{H})$; developmental stages are also shown as $\mathrm{PG}=$ primary growth, $\mathrm{CA}=$ cortical alveoli, $\mathrm{Vtg} 1=$ early vitellogenic, $\mathrm{Vtg} 2=$ mid-vitellogenic, $\mathrm{Vtg} 3=$ advanced vitellogenic, $\mathrm{At}=$ atretic, $\mathrm{POF}=$ post-ovulatory follicles, $\mathrm{OW}=$ ovarian wall 


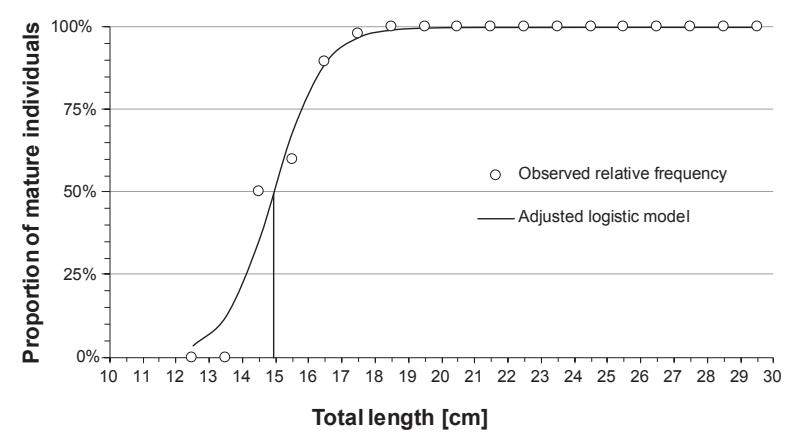

Fig. 4. Logistic curves of relative frequency of mature females of Sphoeroides nephelus as function of size class ( $1 \mathrm{~cm}$ intervals); the size at $50 \%$ maturity $\left(L_{50}\right)$ was estimated at $14.93 \mathrm{~cm}$ TL

$K_{\mathrm{n}}$, decreased considerably after February-March (Fig. $7 \mathrm{C}$ ), in which case although the monthly variation was statistically significant in males $\left(F_{222,11}=2.81, p\right.$-value $=$ $0.002)$, it was not significant in females $\left(F_{188,11}=1.83\right.$, $p$-value $=0.052)$.

Oocyte development and fecundity. Oocytes in different stages of development were observed at the following ranges and means ( \pm standard deviation): 120-230 $\mu \mathrm{m}(168.8 \pm 27.3 \mu \mathrm{m})$ for CA, 290-480 $\mu \mathrm{m}$ $(368.4 \pm 53.1 \mu \mathrm{m})$ for $\mathrm{Vtg} 1,430-590 \mu \mathrm{m}(513.8 \pm 39.6$ $\mu \mathrm{m})$ for $\mathrm{Vtg} 2,540-690 \mu \mathrm{m}(617.2 \pm 28.3 \mu \mathrm{m})$ for $\mathrm{Vtg} 3$. Oocyte development in $S$. nephelus was considered asynchronous because

- oocytes at different stages of development were simultaneously present in the ovary in spite of the gonadal development and

- the oocyte size-frequency distributions showed a continuous size-frequency development of oocytes, except for spawning capable ovaries which, along with all the secondary growth stages, had a separate mode of the most advanced oocytes developed for subsequent ovulation (Fig. 8).

In addition, the presence of massive atresia of vitellogenic oocytes in females in the regressing phase of gonadal development indicates that fecundity should be considered as indeterminate, thus, fecundity was estimated as batch fecundity.

Batch fecundity was estimated only from 24 females that showed signs of advanced gonadal development and presence of Vtg2-3 oocytes, which showed a separate mode of mature oocytes developed previously to ovulation. The size range of the females used to fecundity estimation was from 16.4 to $29.8 \mathrm{~cm}$ TL (74.4 to $393 \mathrm{~g}$ $W_{\mathrm{E}}$ ) (Fig. 9). The relation between batch fecundity and total length (Fig. 9A) was fitted to a power regression model, while a linear regression model was used for the weight (Fig. 9B). Fecundity ranged between 59087 and 367022 oocytes per spawning batch, with the mean value of 176456 oocytes per spawning batch. The relative batch fecundity ( \pm standard deviation) was estimated at $828 \pm$ 182 oocytes per gram of eviscerated weight, and $11989 \pm$ 4774 oocytes per gram of gonad weight.

\section{DISCUSSION}

This study described for the first time the reproductive traits of the southern pufferfish, Sphoeroides nephelus. Only a single male of $14.1 \mathrm{~cm}$ TL was identified as immature, whereas 16 females, ranging from 12.9 to 17.5 $\mathrm{cm}$ TL, showed immature histological characteristics. Therefore, the size at $50 \%$ maturity $\left(L_{50}\right)$ was estimated only for females at $14.93 \mathrm{~cm}$ TL. In other species of Sphoeroides the $L_{50}$ has been estimated to be approximately $28 \%-33 \%$ of maximum size (Mallard-Colmenero et al. 1982, Rocha et al. 2002). If sexual maturity is reached at a similar percentage of maximum size in $S$. nephelus, which grows to $30 \mathrm{~cm}$ TL (Froese and Pauly 2018), this would put the length at sexual maturity at least at 8.4-9.9 cm TL.

The overall $1 \div 1$ sex ratio for $S$. nephelus in our study differs from that observed in other species of Sphoeroides, where there was a greater proportion of males during the reproductive periods. This is the case of Sphoeroides annulatus (Jenyns, 1842) (see Sánchez-Cárdenas et al. 2007), Sphoeroides greeleyi Gilbert, 1900 (see Schultz et al. 2002), Sphoeroides testudineus (Linnaeus, 1758) (see Rocha et al. 2002), and Sphoeroides maculatus (Bloch et Schneider, 1801) (see Laroche and Davis 1973). However, from a temporal (monthly) point of view, the skewed sex ratios of $S$. nephelus (more males from October to February whereas more females from April to September) might suggest some sort of migration by one sex in relation to a spawning behaviour of the species. In March, when the greater reproductive activity occurs, the sex ratio was more balanced. It has been acknowledged that the seasonal migrations in fish evolve when the quality of sites varies in suitability for different parts of the life cycle, such as breeding (Hunter et al. 2004). This finding is similar to the studies in other pufferfishes, e.g., Torquigener pleurogramma (Regan, 1903) (see Potter et al. 1988) or Marilyna pleurosticta (Günther, 1872) and Tetractenos hamiltoni (Richardson, 1846) (see Piah and Bucher 2014), whose mature specimens migrate out of the estuary to spawn in shallow coastal waters. The majority of the females of $S$. nephelus probably leave the coastal zone and migrate towards mangroves or seagrass areas during the winter season. The latter is characterized by northern cold fronts, locally known as 'nortes'. The pufferfish females leave those shallow ecosystems in early spring moving towards the open sea area for reasons other than a spawning migration.

In our study, $S$. nephelus showed a protracted reproductive period from August to May, with a peak between February and March, and their period of reproductive inactivity in June and July. Sex differences in the timing of seasonal breeding (one-month lag at the onset of the spawning) may be due to the differential response to environmental cues regulating the onset and end of the spawning. In this regard, sexes can be expected to differ in the cues they use to time reproduction. For instance, it could be regulated via the response to photoperiod or in the relative importance and action of supplementary factors (such as temperature, food supply, and behavioural interactions) that adjust the timing of 

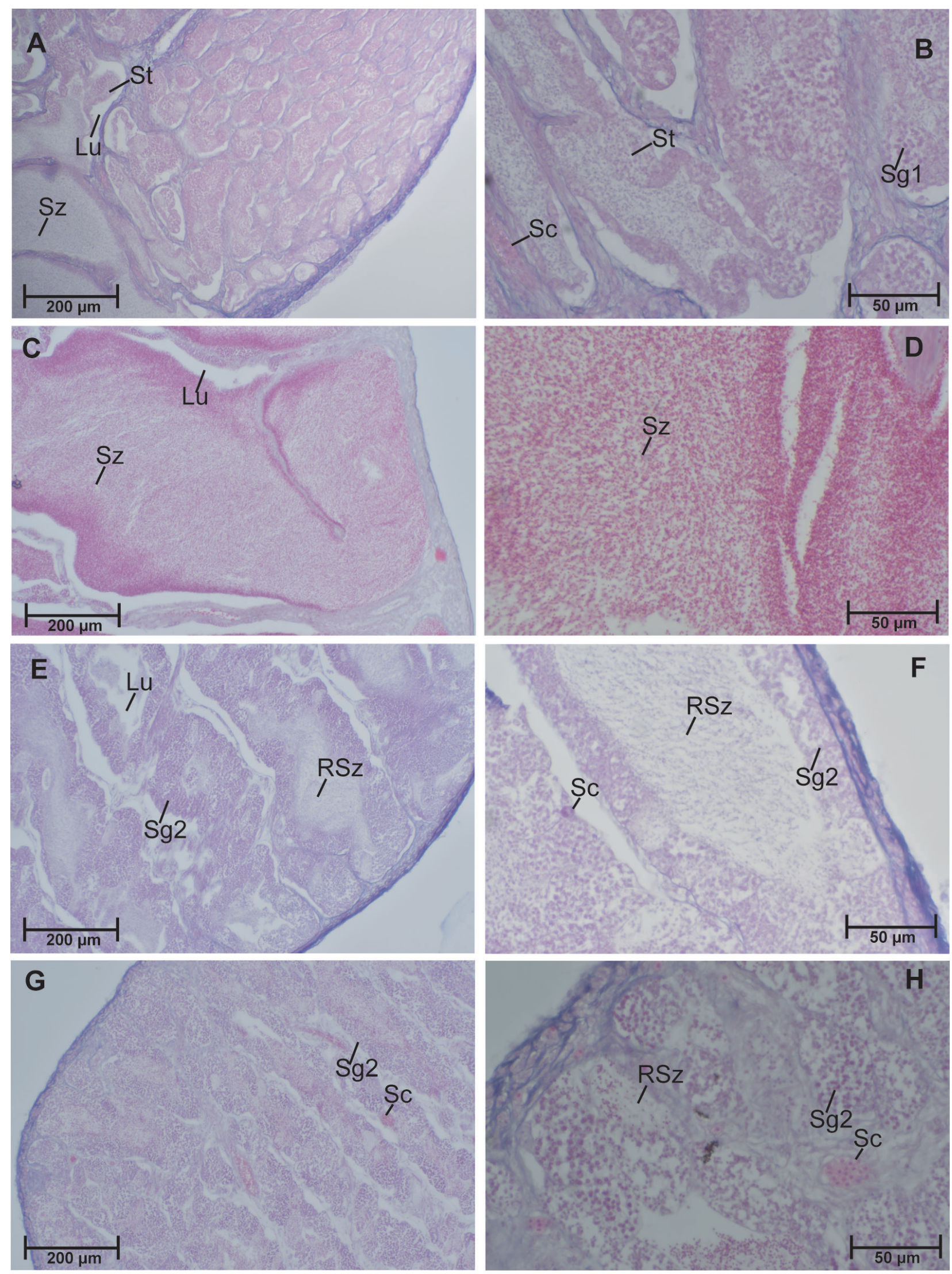

Fig. 5. Microphotographs of male gonads of Sphoeroides nephelus showing the reproductive phases considered in this study: developing $(\mathbf{A}, \mathbf{B})$, spawning capable $(\mathbf{C}, \mathbf{D})$, regressing $(\mathbf{E}, \mathbf{F})$, and regenerating $(\mathbf{G}, \mathbf{H})$; developmental stages are also shown as $\mathrm{Sg} 1$ = primary spermatogonia, $\mathrm{Sg} 2=$ secondary spermatogonia, $\mathrm{Sc}=$ spermatocyte, $\mathrm{St}=$ spermatid, $\mathrm{Sz}=$ spermatozoa, $\mathrm{Rsz}=$ residual spermatozoa, $\mathrm{Lu}=$ lumen 
reproduction. Similar studies concerning reproductive biology in other species of Sphoeroides have determined different reproductive periods. In the Chesapeake Bay in the United States, $S$. maculatus shows a reproductive peak in June and July (Laroche and Davis 1973). In the Gulf of Mexico, S. testudineus reproduces from June to January, with peaks in October and November (Tzeek Tuz 2013). In the Mexican Pacific, $S$. annulatus has two reproductive periods, one from April to August and the other from October to November (Sánchez-Cárdenas et al. 2007).

Females of $S$. nephelus, in our study, showed no significant correlation between the GSI and the HSI; however, these indices were significantly correlated in males. Meanwhile the correlation between the HSI and the $K_{\mathrm{n}}$ was significant in both sexes, suggesting that although the liver is not the main energy storage organ in this species, it presumably has some relation to fish condition, playing a role in nutrient transfer between different organs (in particular, lipids that are not used immediately could be transferred from the liver to the muscle and viscera and may later be used in reproduction). In this regard, poor somatic condition in fish during the spawning season has been acknowledged to give an indication that the somatic growth is limited due to the development of gonads (García-Díaz et al. 2006), and the decrease in condition has been ascribed to a depletion of body reserves during gonad maturation (Murua and SaboridoRey 2003). Moreover, regarding the seasonality of the fish condition indices, HSI and $K_{\mathrm{n}}$, after the months of greatest reproductive activity (February to March), it was observed that both values decreased considerably, recovering in the months of the reproductive inactivity. However, this monthly variation was statistically significant only in males and not significant in females. For both sexes, when the HSI values were at their minimal level, the GSI values were the highest and this condition suggesting the point that the liver has a weight loss during reproduction which may indicate the mobilization of hepatic reserves for gonads maturation. In addition, higher $K_{\mathrm{n}}$ values were observed in both sexes within the preceding month (January) of greatest reproductive activity, which in turn means that the energy reserves probably are stored also as body fat before reproduction.

Our observations indicated that $S$. nephelus shows an asynchronous development of oocytes and indeterminate fecundity, being a characteristic of other species of the genus. This is similar to $S$. greeleyi (see Schultz et al. 2002) and S. testudineus (see Rocha et al. 2002). The mean relative batch fecundity of $S$. nephelus was estimated at $828 \pm 182$ oocytes $\cdot \mathrm{g}^{-1} W_{\mathrm{E}}$, and $11989 \pm 4774$ oocytes - $\mathrm{g}^{-1} W_{\mathrm{G}}$. Similar results were obtained in $S$. maculatus regarding the number of oocytes $\cdot \mathrm{g}^{-1} W_{\mathrm{E}}$ (Merriner and Laroche 1977), although the relative batch fecundity to the $W_{\mathrm{G}}$ was lower than that found for $S$. nephelus.

Our study of Sphoeroides nephelus in the Yucatan Peninsula, Mexico, represents the first description of the reproductive biology of this puffer species. This kind of information might serve as a point of reference for its

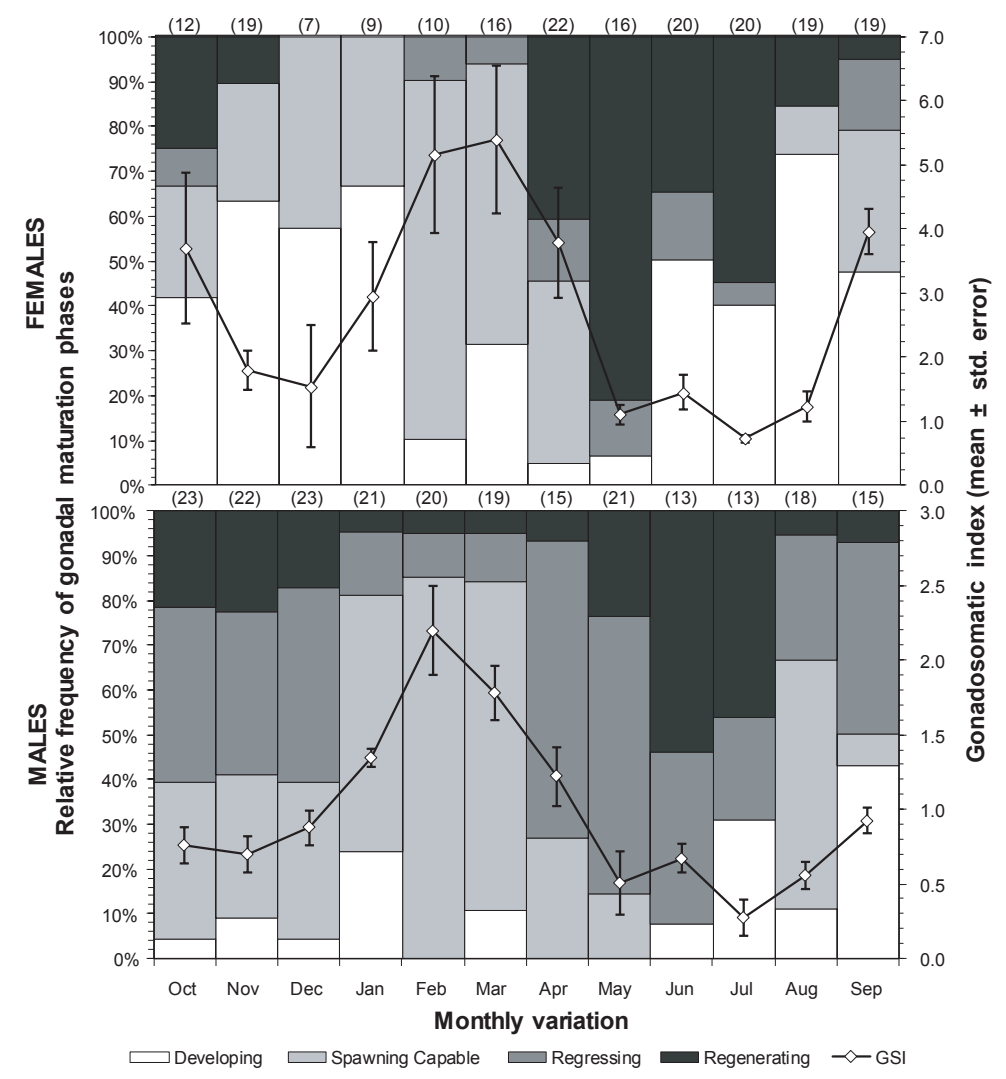

Fig. 6. Reproductive cycle and mean ( \pm standard error) variation in the gonadosomatic index (GSI) of Sphoeroides nephelus per sex at the coast off Chuburná Puerto, northern coast of the Yucatan Peninsula, Mexico; sample number (n) per month is also given above bars 
potential use either in the pharmaceutical industry as well as in aquaculture for human consumption. In this latter sense there is a controversy about the toxicity of $S$. nephelus, because some studies mention that their meat is safe to consume by humans (Burklew and Morton 1971), while recent studies has identified a certain degree of toxicity related to regional variations (Etheridge et al. 2006, Deeds et al. 2008, Abbott et al. 2009) and may be harmful to humans. However, in other puffer species, it has been observed that their toxicity may be considerably reduced when pufferfishes are grown in controlled systems and make them suitable for human consumption (Noguchi et al. 2006, Chávez Sánchez et al. 2008, Arakawa et al. 2010). This latter approach would represent a possible opportunity for further studies whose aim would be to explore whether toxicity in $S$. nephelus is reduced in captivity and then the specimens are reared to suitable sizes for consumption. But in case when the toxicity cannot be reduced in captivity, other puffer species have been used by the pharmaceutical industry to use of TTX as a molecular precursor of other substances (Mitra et al. 1989, Ghosh et al. 2005, Kosker et al. 2016), and this would also may represent another reason to culture specimens of $S$. nephelus. Therefore, in either case, it would be helpful to obtain a broodstock (sexually mature specimens) that would be the base to produce fingerlings to be raised as a batch for a few weeks or months before harvesting in fish seed farms, instead of collecting individuals from the wild.

More pre-spawning information is required such as maintenance, maturation, acclimatization, hormonal spawning induction, and hatching. Post-spawning information is also needed, such as water quality management, broodstock handling, assessment of fish condition, and health management. All these pre- and post-spawning studies would lead to better breeding responses and increased fecundity, fertilization, hatching and larval survival rates and more viable fish seed. Owning a broodstock bank of marine fish would allow glimpsing the option of supporting those interested in aquaculture and face the marine fish market in a sustainable manner, and if needed $S$. nephelus would represent an alternative option to the currently most demanded marine products.

Conclusions. Several reproductive traits of Sphoeroides nephelus were determined,e.g., $1 \div 1$ sex ratio, an asynchronous development of oocytes and indeterminate fecundity with batch spawning, as well as a protracted reproductive season
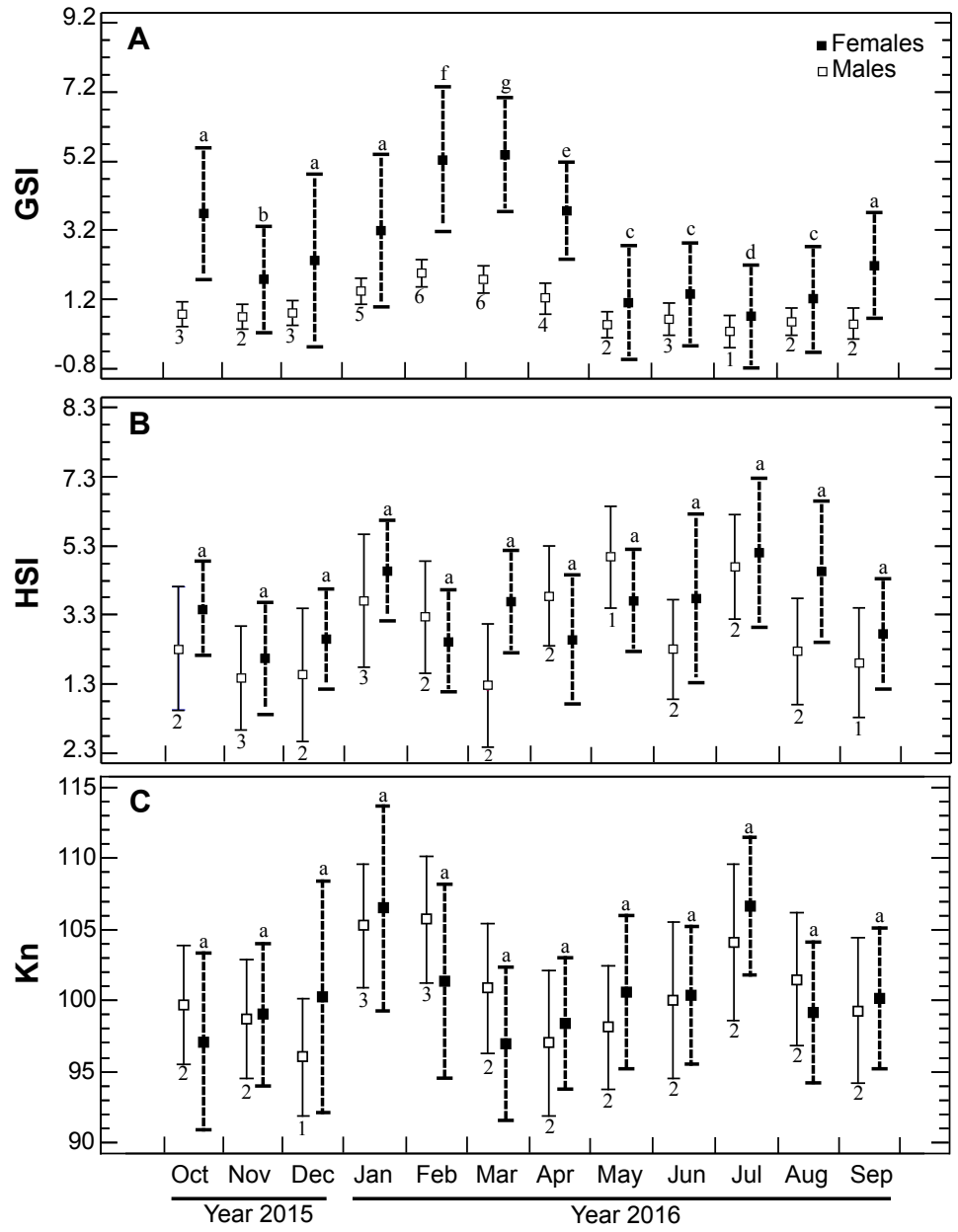

Fig. 7. Monthly means ( $\pm 95 \%$ Bonferroni's intervals) of (A) the gonadosomatic index (GSI), (B) the hepatosomatic index (HSI), and (C) the relative condition factor $(\mathrm{Kn})$ of Sphoeroides nephelus per sex (To determine which groups of values are different, letters were placed for females and numbers for males) 
almost all year around. This latter information would be helpful to obtain a broodstock (sexually mature specimens) that would be the base to produce fingerlings to be raised, instead of collecting individuals from the wild.

\section{ACKNOWLEDGEMENTS}

We thank M.M. Arjona-Torres and Fanny C. SánchezCámara for their support and advice provided in the preparation and assembly of the histological samples. To the National Council of Science and Technology for the grant awarded to Jorge Carlos Peniche-Pérez. This work received partial support of the Programa de Apoyo al Desarrollo y Consolidación de los Cuerpos Académicos (PADECCA) from

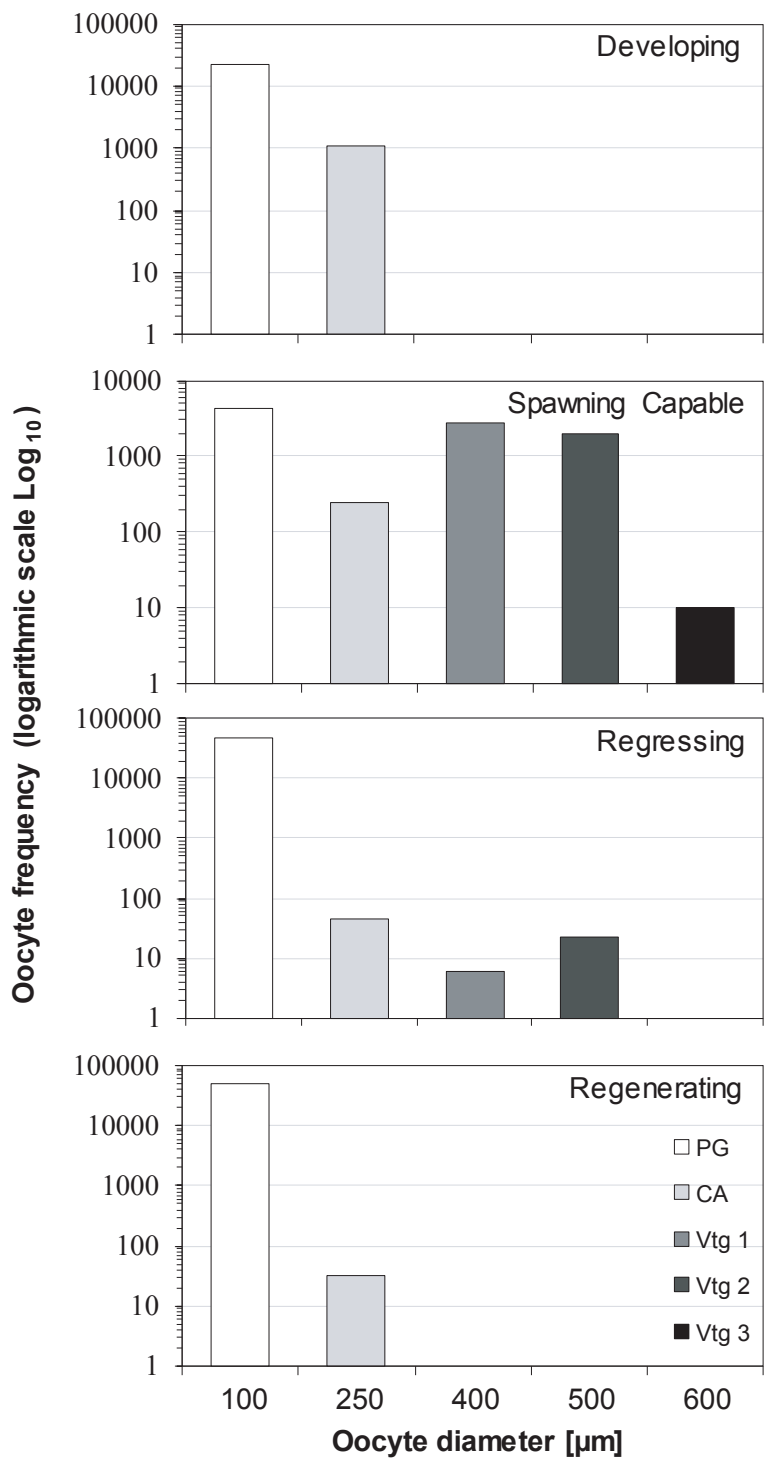

Fig. 8. Oocyte size-frequency distributions per diameter through subsequent gonadal development phases of Sphoeroides nephelus; each distribution corresponds to an individual female of 'standard' $26.0 \mathrm{~cm}$ TL; the range of oocytes diameters at different stages of development is also illustrated as follows: primary growth (PG), cortical alveoli (CA), early vitellogenesis (Vtg1), mid vitellogenesis (Vtg2), advanced vitellogenesis (Vtg3) the Universidad Autónoma de Yucatán. Finally, we would like to thank the reviewers for their thoughtful comments and efforts towards improving our manuscript.

\section{REFERENCES}

Abbott J.P., Flewelling L.J., Landsberg J.H. 2009. Saxitoxin monitoring in three species of Florida puffer fish. Harmful Algae 8 (2): 343-348. DOI: 10.1016/j. hal.2008.07.005

Abdo de la Parra M., Rodríguez-Ibarra L., GarcíaAguilar N., Velasco-Blanco G., Ibarra-Castro L. 2013. Biotecnología para la producción masiva de juveniles del botete diana Sphoeroides annulatus: Inducción hormonal y cultivo larvario. Revista de Biología Marina y Oceanografia 48 (3): 409-420. DOI: $10.4067 / \mathrm{S} 0718-19572013000300001$

Arakawa O., Hwang D.-F., Taniyama S., Takatani T. 2010. Toxins of pufferfish that cause human intoxications. Pp. 227-244. In: Ishimatsu A., Lie H.J. (eds.) Coastal environmental and ecosystem issues of the East China Sea. TERRAPUB, Tokyo and Nagasaki University, Nagasaki, Japan.

Awruch C.A., Lo Nostro F.L., Somoza G.M., Di Giácomo E. 2008. Reproductive biology of the angular angel shark Squatina guggenheim (Chondrichthyes: Squatinidae) off Patagonia (Argentina, southwestern Atlantic). Biología reproductiva del tiburón ángel Squatina guggenheim (Chondrichthyes: Squatinidae) en la costa de Patagonia (Argentina, Atlántico suroeste). Ciencias Marinas 34 (1): 17-28. DOI: 10.7773/cm.v34i1.1232

Brown-Peterson N.J., Wyanski D.M., Saborido-Rey F., Macewicz B.J., Lowerre-Barbieri S.K. 2011. A standardized terminology for describing reproductive development in fishes. Marine and Coastal Fisheries: Dynamics Management and Ecosystem Science 3 (1): 52-70. DOI: $10.1080 / 19425120.2011 .555724$

Burklew M.A., Morton R.A. 1971. The toxicity of Florida gulf puffers, genus Sphoeroides. Toxicon 9 (3): 205-210. DOI: 10.1016/0041-0101(71)90071-7

Carr W.E.S., Adams C.A. 1973. Food habits of juvenile marine fishes occupying seagrass beds in the estuarine zone near Crystal River, Florida. Transactions of the American Fisheries Society 102 (3): 511-540. DOI: $\quad 10.1577 / 1548-8659(1973) 102<511$ :FHOJMF $>$ 2.0.CO;2

Chávez Sánchez M.C., Álvarez-Lajonchére L., Abdo de la Parra M.I., Garcia Aguilar N. 2008. Advances in the culture of the Mexican bullseye puffer fish Sphoeroides annulatus, Jenyns (1842). Aquaculture Research 39 (7): 718-730. DOI: 10.1111/j.13652109.2008.01924.x

Collette B.B. 2002. Volume 3: Bony fishes part 2 (Opistognathidae to Molidae), sea turtles and marine mammals. Pp. 1412-1413. In: Carpenter K.E. (ed.) The living marine resources of the western central Atlantic: FAO species identification guide for fishery purposes and American Society of Ichthyologists and Herpetologists Special publication No. 5. FAO, Rome. 


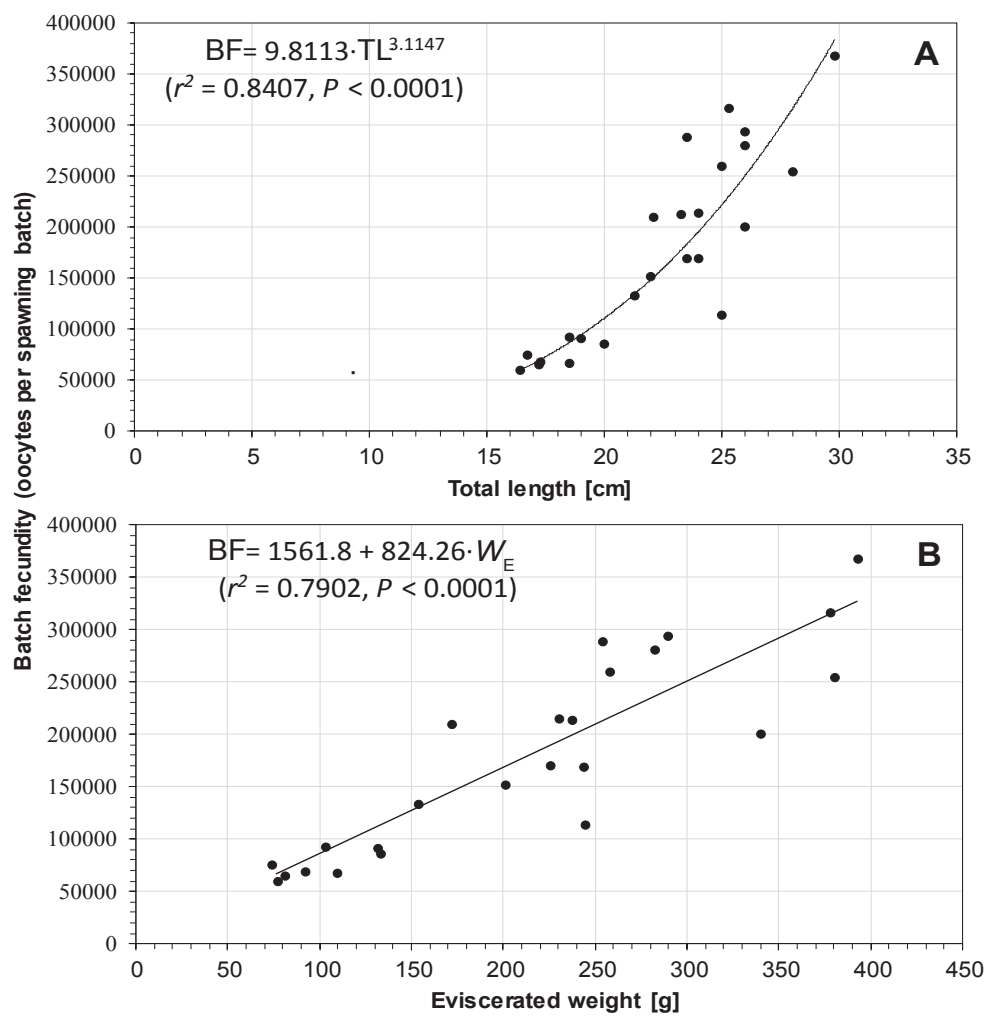

Fig. 9. Fitted regression models for 24 females of Sphoeroides nephelus based on batch fecundity (No. of oocytes per spawning batch) related to total length (A) by a power model and eviscerated weight (B) by a linear model; TL $=$ total length, $\mathrm{BF}=$ batch fecundity, $W_{\mathrm{E}}=$ eviscerated weight, $P=p$-value

Copp G.H. 2003. Is fish condition correlated with water conductivity? Journal of Fish Biology 63 (1): 263266. DOI: 10.1046/j.1095-8649.2003.00145.x

deVlaming V., Grossman G., Chapman F. 1982. On the use of the gonosomatic index. Comparative Biochemistry and Physiology Part A: Physiology 73 (1): 31-39. DOI: 10.1016/0300-9629(82)90088-3

Deeds J.R., Landsberg J.H., Etheridge S.M., Pitcher G.C., Longan S.W. 2008. Non-traditional vectors for paralytic shellfish poisoning. Marine Drugs 6 (2): 308-348. DOI: $10.3390 / \mathrm{md} 20080015$

Dore I. 1991. The new fresh seafood buyer's guide: A manual for distributors, restaurants and retailers. Van Nostrand Reinhold, New York, NY, USA.

Etheridge S.M., Deeds J.R., White K., Flewelling L.J., Abbott J.P., Landsberg J.H., Conrad S.M., Bodager D., Jackow G. 2006. Detection methods and their limitations: PSP toxins in the southern puffer fish Sphoeroides nephelus responsible for human poisoning events in Florida in 2004. African Journal of Marine Science 28 (2): 383-387. DOI: 10.2989/18142320609504183

Froese R., Pauly D. (eds.) 2018. FishBase. [Version 06/2018] http://www.fishbase.org

García-Díaz M., González J.A., Lorente M.J., Tuset V.M. 2006. Spawning season, maturity sizes, and fecundity in blacktail comber (Serranus atricauda) (Serranidae) from the Eastern-central Atlantic. Fishery Bulletin 104 (2): 159-166.
Ghosh S., Hazra A.K., Banerjee S., Mukherjee B. 2005. Ecological monitoring for ascertaining the bio-safety of liver lipids from some Indian marine puffer fishes. Fisheries Science 71 (1): 29-37. DOI: 10.1111/j.14442906.2005.00927.x

Gonçalves P., Costa A.M., Murta A.G. 2009. Estimates of batch fecundity and spawning fraction for the southern stock of horse mackerel (Trachurus trachurus) in ICES Division IXa. ICES Journal of Marine Science 66 (4): 617-622. DOI: 10.1093/icesjms/fsp066

Herrera-Silveira J.A. 1994. Spatial heterogeneity and seasonal patterns in a tropical coastal lagoon. Journal of Coastal Research 10 (3): 738-746.

Hunter E., Metcalfe J.D., Arnold G.P., Reynolds J.D. 2004. Impacts of migratory behaviour on population structure in North Sea plaice. Journal of Animal Ecology 73 (2): 377-385. DOI: 10.1111/j.0021-8790.2004.00801.x

Hunter J.R., Lo N.C.H., Leong R.J.H. 1985. Batch fecundity in multiple spawning fishes. Pp. 67-78. In: Lasker R. (ed.) An egg production method for estimating spawning biomass of pelagic fish: Application to the northern anchovy, Engraulis mordax. NOAA Technical Report NMFS 36.

Hunter J.R., Macewicz B.J. 1985. Rates of atresia in the ovary of captive and wild northern anchovy, Engraulis mordax. Fishery Bulletin 83 (2): 119-136.

Kosker A.R., Özogul F., Durmus M., Ucar Y., Ayas D., Regenstein J.M., Özogul Y. 2016. Tetrodotoxin levels in pufferfish (Lagocephalus sceleratus) 
caught in the northeastern Mediterranean Sea. Food Chemistry 210: 332-337. DOI: 10.1016/j. foodchem.2016.04.122

Kraus G., Müller A., Trella K., Köster W. 2005. Fecundity of Baltic cod: Temporal and spatial variation. Journal of Fish Biology 56 (6): 1327-1341. DOI: $10.1006 /$ jfbi.2000.1251

Landsberg J.A., Sherwood H., Johannessen J.N., White K.D., Conrad S.M., Abbott J.P., Flewelling L.J., Richardson R.W., Dickey R.W., Jester E.L.E., Etheridge S.M., Deeds J.R., Van Dolah F.M., Leighfield T.A., Zou Y., Beaudry C.G., Benner R.A., Rogers P.A., Scott P.S., Kawabata K., Wolny J.L., Steidinger K.A. 2006. Saxitoxin puffer fish poisoning in the United States, with the first report of Pyrodinium bahamense as the putative toxin source. Environmental Health Perspectives 114 (10): 15021507. DOI: $10.1289 /$ ehp. 8998

Laroche J.L., Davis J. 1973. Age, growth and reproduction of the northern puffer, Sphoeroides maculatus. Fishery Bulletin 71 (4): 955-963.

Le Cren E.D. 1951. The length-weight relationship and seasonal cycle in gonad weight and condition in the perch Perca fluviatilis. Journal of Animal Ecology 20 (2): 201-219. DOI: 10.2307/1540

Lowerre-Barbieri S.K., Barbieri L.R. 1993. A new method of oocyte separation and preservation for fish reproduction studies. Fishery Bulletin 91 (1): 165-170.

Lowerre-Barbieri S.K., Brown-Peterson N.J., Murua H., Tomkiewicz J., Wyanski D.M., SaboridoRey F. 2011. Emerging issues and methodological advances in fisheries reproductive biology. Marine and Coastal Fisheries: Dynamics Management and Ecosystem Science $\mathbf{3}$ (1): 32-51. DOI: 10.1080/19425120.2011.555725

Mallard-Colmenero L., Yáñez-Arancibia A., Amezcua-Linares F. 1982. Taxonomía, diversidad, distribución y abundancia de los tetraodontidos de la Laguna de Términos, sur del Golfo de México (Pisces: Tetraodontidae). Anales del Instituto de Ciencias del Mar y Limnología 9 (1): 161-212.

McConney P. 2011. Coastal fisheries of Barbados. Pp. 49-71. In: Salas S., Chuenpagdee R., Charles A., Seijo J.C. (eds.) Coastal fisheries of Latin America and the Caribbean. FAO Fisheries and Aquaculture Technical Paper. No. 544. FAO, Rome.

Merriner J., Laroche J. 1977. Fecundity of the northern puffer, Sphoeroides maculatus, from Chesapeake Bay. Chesapeake Science 18 (1): 81-83. DOI: $10.2307 / 1350368$

Mitra S.K., Sanyal B., Ganguly S.N., Mukherjee B. 1989. A hypnotic barbitone from Sphaeroides oblongus (Bloch). Journal of the Chemical Society, Chemical Communications 1 (1): 16. DOI: 10.1039/ c39890000016

Murua H., Kraus G., Saborido-Rey F., Witthames P.R., Thorsen A., Junquera S. 2003. Procedures to estimate fecundity of marine fish species in relation to their reproductive strategy. Journal of Northwest
Atlantic Fishery Science 33: 33-54. DOI: 10.2960/J. v33.a3

Murua H., Saborido-Rey F. 2003. Female reproductive strategies of marine fish species of the North Atlantic. Journal of Northwest Atlantic Fishery Science 33: 23 31. DOI: $10.2960 /$ J.v33.a2

Noguchi T., Arakawa O., Takatani T. 2006. Toxicity of puffer fish cultured in netcages at sea or aquaria on land. Comparative Biochemistry and Physiology Part D: Genomics and Proteomics 1 (1): 153-157. DOI: 10.1016/j.cbd.2005.11.003

Oliveira J.S., Pires Junior O.R., Morales R.A.V., Bloch Junior C., Schwartz C.A., Freitas J.C. 2003. Toxicity of puffer fish-Two species (Lagocephalus laevigatus, Linaeus 1766 and Sphoeroides spengleri, Bloch 1785) from the southeastern Brazilian coast. Journal of Venomous Animals and Toxins Including Tropical Diseases 9 (1): 76-88. DOI: 10.1590/S167891992003000100005

Ordoñez-López U., Huchin-Sel R., Peniche-Pérez J., Gallegos-Fernández S., Sosa-Pinto R., Vásquez-Yeomans L. 2013. Variación temporal del ictioplancton colectado con trampas de luz en los puertos de Chuburná y Yucalpetén, Yucatán, México. Hidrobiológica 23 (2): 265-273.

Palacios-Sánchez S.E., Vega-Cendejas M.E. 2010. Cambios alimenticios en tres especies de Sphoeroides (Tetraodontiformes: Tetraodontidae) posterior al huracán Isidoro en bocana de la Carbonera, Sureste del Golfo de México. Revista de Biologia Tropical 58 (4): 1223-1235. DOI: 10.15517/rbt.v58i4.5407

Pauly D., Palomares M.L. 2005. Fishing down marine food web: It Is far more pervasive than we thought. Bulletin of Marine Science 76 (2): 197-211.

Piah R.M., Bucher D.J. 2014. Reproductive biology of estuarine pufferfish, Marilyna pleurosticta and Tetractenos hamiltoni (Teleostei: Tetraodontidae) in northern New South Wales: Implications for biomonitoring. Proceedings of the Linnean Society of New South Wales 136 (1): 219-229.

Poot-Salazar A., Pérez-Castañeda R., Vega-Cendejas M.E., Defeo O. 2009. Assessing patterns of ichthyofauna discarded by an artisanal shrimp fishery through selectivity experiments in a coastal lagoon. Fisheries Research 97 (3): 155-162. DOI: 10.1016/j. fishres.2009.02.001

Poot-López G.R., Díaz-Gamboa R., González-Salas C., Guillén-Hernández S. 2017. Length-weight relationships of three fish species collected by recreational fishing in the northern coast of Yucatan Peninsula, Mexico. Journal of Applied Ichthyology 33 (6): 1249-1250. DOI: 10.1111/jai.13442

Potter I.C., Cheal A.J., Loneragan N.R. 1988. Protracted estuarine phase in the life cycle of the marine pufferfish Torquigener pleurogramma. Marine Biology 98 (3): 317-329. DOI: 10.1007/BF00391107

Rocha C., Favaro L.F., Spach H.L. 2002. Biología reproductiva de Sphoeroides testudineus (Linnaeus) (Pisces, Osteichthyes, Tetraodontidae) da gamboa do 
Baguaçu, Baía de Paranaguá, Paraná, Brasil. Revista Brasileira de Zoologia 19 (1): 57-63. DOI: 10.1590/ S0101-81752002000100003

Sala E.,Aburto-Oropeza O., Reza M.,Paredes G.,LópezLemus L.G. 2004. Fishing down coastal food webs in the Gulf of California. Fisheries 29 (3): 19-25. DOI: 10.1577/1548-8446(2004)29[19:FDCFWI]2.0.CO;2

Sánchez-Cárdenas R., Ceballos-Vázquez B.P., Arellano-Martínez M., Valdez-Pineda M.C., Morán-Angulo R.E. 2007. Reproductive aspects of Sphoeroides annulatus (Jenyns, 1842) (Tetraodontiformes, Tetraodontidae) inhabiting the Mazatlan coast, Sinaloa, Mexico. Revista de Biología Marina y Oceanografía 42 (3): 385-392. DOI: $10.4067 /$ S0718-19572007000300018

Santos R.S., Hawkins S.J., Nash R.D.M. 1996. Reproductive phenology of the Azorean rock pool blenny a fish alternative mating tactics. Journal of Fish Biology 48 (5): 842-858. DOI: 10.1111/j.10958649.1996.tb01480.x

Schultz Y.D., Favaro L.F., Spach H.L. 2002. Aspectos reprodutivos de Sphoeroides greeleyi (Gilbert), Pisces, Osteichthyes, Tetraodontidae, da gamboa do Baguaçu, Baia De Paranaguá, Paraná, Brasil. [Reproductive aspects of Sphoeroides greeleyi (Gilbert) Tetraodontidae, from Gamboa Do Baguacu, State of Parana, Brazil.] Revista Brasileira de Zoologia 19 (1): 65-76. [In Portuguese.] DOI: 10.1590/S010181752002000100004

Tzeek Tuz J.G. 2013. Biología de la reproducción de Strongylura notata y Sphoeroides testudineus, de la laguna "La Carbonera" en Sisal Yucatán. Tesis de Maestría. Universidad Nacional Autónoma de México, México DF, Mexico.
Vega-Cendejas M.E. 2004. Ictiofauna de la reserva de la biosfera Celestún, Yucatán: Una contribución al conocimiento de su biodiversidad. Anales del Instituto de Biología, Universidad Nacional Autónoma de México, Serie Zoología 75 (1): 193-206.

Villacorta-Correa M.A., Saint-Paul U. 1999. Structural indexes and sexual maturity of tamabaqui Colossoma macropomum (Cuvier, 1818) (Characiformes: Characidae) in central Amazon, Brazil. Revista Brasileira de Biologia 59 (4): 637-652. DOI: 10.1590/ S0034-71081999000400013

Villegas-Hernández H., Muñoz M., Lloret J. 2016. Reproductive traits of the pompano, Trachinotus ovatus (Linnaeus, 1758), in the north-western Mediterranean. Journal of the Marine Biological Association of the United Kingdom 96 (5): 1053-1063. DOI: 10.1017/ S0025315415001265

Weinstein M.P., Heck K.L.jr. 1979. Ichthyofauna of seagrass meadows along the Caribbean coast of Panamá and in the Gulf of Mexico: Composition, structure and community ecology. Marine Biology 50 (2): 97-107. DOI: 10.1007/BF00397814

Witthames P.R., Thorsen A., Murua H., SaboridoRey F., Greenwood L., Domínguez-Petit R., Korta M., Kjesbu O.S. 2009. Advances in methods for determining fecundity: Application of the new methods to some marine fishes. Fishery Bulletin 107 (2): 148-164.

Zar J.H. 1999. Biostatistical analysis. 4th edn. Prentice Hall, Upper Saddle River, NJ, USA.

Received: 10 July 2018 Accepted: 22 December 2018 Published electronically: 15 June 2019 